\title{
Relevansi Kewibawaan dan Kewiyataan dengan Hasil Belajar Siswa
}

\author{
Abdillah \\ IAIN Sumatera Utara
}

\begin{abstract}
This paper elaborates student echivement based on authority, education, and quality of students' learning. The study shows that the relationship between authority, education, and quality of students' learning activity toward learning result in middle school category is bigger than high or low school category. The quality of students' learning activity is oppointed by authority and education implemented by the teachers in learning process. The authority, education, and quality of students' learning have relation significantly to the student echivement. The relationship of authority, education, and quality of students' learning is definitly difference in predicting their echivement. Trough authority and education in learning process, the student's echivement can be increased.
\end{abstract}

Keywords: authority, education, quality of learning, student's echivement

\begin{abstract}
Abstrak
Makalah ini mengkaji hasil belajar yang didasarkan pada kewibawaan dan kewiyataan. Kajian ini menunjukkan bahwa hubungan kewibawaan, kewiyataan dan mutu belajar terhadap hasil belajar siswa pada sekolah kategori sedang itu lebih besar daripada sekolah kategori tinggi dan rendah. Tinggi rendahnya mutu kegiatan belajar siswa ditentukan oleh faktor kewibawaan dan kewiyataan yang diimplementasikan oleh guru dalam proses pembelajaran. Kewibawaan, kewiyataan dan mutu kegiatan belajar siswa berhubungan secara signifikan terhadap hasil belajar siswa. Hubungan kewibawaan, kewiyataan dan mutu kegiatan belajar siswa berbeda secara nyata dalam memprediksi hasil belajar siswa. Melalui kewibawaan dan kewiyataan dalam proses pembelajaran siswa dapat ditingkatkan hasil belajarnya.
\end{abstract}

Kata kunci: kewibawaan, kewiyataan, mutu kegiatan belajar dan hasil belajar.

ISSN 1979-1739

(C) 2012 Nadwa | IAIN Walisongo

http://journal.walisongo.ac.id/index.php/nadwa 


\section{A. Pendahuluan}

Kegiatan pendidikan di berbagai lembaga pendidikan diarahkan untuk mencapai tujuan pendidikan nasional. Agar tujuan pendidikan tercapai, Pelaksanaan proses pembelajaran di sekolah harus mengacu kepada Standar Proses Pendidikan yang dituangkan dalam Peraturan Menteri Pendidikan Nasional Republik Indonesia No 41 Tahun 2007 untuk Satuan Pendidikan Dasar dan Menengah yang berbunyi: Sebagai lembaga yang diharapkan memberikan kontribusi yang besar terhadap pencapaian tujuan pendidikan nasional, sebuah sekolah harus bisa menghasilkan lulusan yang berkualitas.

Apabila kualitas lulusan suatu sekolah bagus berarti sebagian tujuan pendidikan nasional sudah tercapai. Sebaliknya, bila kualitas lulusan suatu sekolah kurang bagus, maka kurang tercapai pula tujuan pendidikan nasional. Kualitas pendidikan dapat tercapai apabila dalam proses pembelajaran terjadi saling sinergi antara guru, siswa dan lingkungan pembelajaran sehingga terjadi proses pembelajaran yang baik sesuai dengan standar proses yang telah digariskan.

Untuk melihat kualitas pendidikan dapat diketahui dari berbagai indikator pendidikan. Salah satu indikatornya adalah hasil belajar siswa. Apabila hasil belajar siswa bagus, maka dikatakan siswa tersebut berkualitas hal ini berarti proses pembelajaran sudah berjalan dengan baik. Begitu juga sebaliknya jika hasil belajarnya jelek, dikatakan bahwa siswa tersebut kurang berkualitas dan hal ini menunjukkan bahwa proses pembelajaran tidak berjalan sebagaimana mestinya.

Bagaimana kondisi kualitas atau mutu pendidikan di Indonesia? Ternyata dari berbagai survei yang telah dilaksanakan baik oleh badan independen maupun perseorangan menyimpulkan bahwa mutu pendidikan di Indonesia masih rendah yang hal ini antara lain ditunjukkan melalui hasil ujian nasional (UN) yang pencapaiannya masih jauh dari yang diharapkan. Bahkan pada tahun 2009 ada 33 sekolah yang tidak lulus 100\% sehingga harus dilakukan ujian pengganti. Walaupun hasil belajar siswa di mana salah satu indikatornya dapat dilihat melalui hasil UN masih bersifat kontroversial, namun setidaknya hal tersebut memberikan gambaran bahwa secara umum hasil belajar siswa masih rendah. 
Fenomena rendahnya hasil belajar siswa terjadi juga di Kabupaten Tanah Datar khususnya pada Sekolah Menengah Pertama (SMP). Rata-rata hasil UN pada tahun 2009/2010 sebesar 6,1 berada pada urutan XIX dan pada tahun 2011/2012 sebesar 6,2 berada pada urutan XVI dari 20 rayon yang ada di Sumatera Barat. Padahal Alokasi dana pendidikan Kabupaten Tanah Datar menempati urutan kedua terbesar Provinsi. (Sumber: Dinas Pendidikan Provinsi)

Rendahnya hasil belajar siswa seperti di sebutkan di atas banyak dipengaruhi oleh berbagai faktor. Gagne berpendapat bahwa hasil belajar siswa dipengaruhi oleh faktor internal siswa maupun eksternal. Faktor internal meliputi motivasi belajar, kecerdasan intelegensi siswa, minat dan perhatian, sikap dan kebiasaan belajar, ketekunan, sosial ekonomi, serta faktor fisik dan psikis. Faktor eksternal meliputi guru, perangkat kurikulum, sarana dan prasarana, dana, dan manajemen. ${ }^{1}$

Mutu kegiatan belajar merupakan salah satu faktor internal yang terkait langsung dengan hasil belajar siswa. Mutu kegiatan belajar siswa adalah kualitas aktivitas belajar siswa yang berkaitan dengan cara-cara bagaimana siswa melakukan kegiatan belajar yang mencakup kondisi prasyarat penguasaan materi pada diri peserta didik, keterampilan belajar, sarana prasarana, dan lingkungan fisik-sosio emosional siswa dalam proses pembelajaran. Penelitian yang dilakukan oleh Yusri dan Dasniwati di sekolah SD dan SMA Negeri di Kota Padang mengungkapkan bahwa mutu kegiatan belajar siswa turut menentukan tinggi rendahnya hasil belajar siswa dan terkait erat dengan proses pembelajaran yang dilakukan di sekolah. ${ }^{2}$

Proses pembelajaran sebagai wujud operasionalisasi praktik pendidikan yang dilaksanakan oleh guru harus mengandung unsur penerimaan dan pengakuan, kasih sayang dan kelembutan, penguatan, tindakan tegas yang mendidik, keteladanan dan pengarahan sebagai perangkat hubungan yang mempertautkan peserta didik dengan pendidik yang diistilahkan dengan kewibawaan (hightouch). Unsur lain yang penting dalam proses

${ }^{1}$ Gagne, The Conditions of Learning (New York: Holt, Rinehart and Winston, 1997), hlm. 75.

2 Yusri, Proses Pembelajaran dan Hubungannya dengan Kegiatan Belajar Siswa: Studi pada Sekolah Menengah Atas Padang, Tesis; Program Pascasarjana Universitas Negeri Padang, 2006. 
pembelajaran yang harus diperhatikan guru adalah penguasaan materi pembelajaran, metode pembelajaran, alat bantu pembelajaran, lingkungan pembelajaran dan penilaian hasil pembelajaran sebagai perangkat praktik pembelajaran yang diistilahkan dengan Kewiyataan (hightech). ${ }^{3}$

Pokja Pengembangan Peta Keilmuan Pendidikan mengemukakan bahwa kewibawaan (hightouch) adalah "alat pendidikan" yang diaplikasikan oleh pendidik untuk menjangkau (to touch) kemandirian peserta didik dalam hubungan pendidikan yang mengarah kepada kondisi hightouch, dalam arti perlakuan pendidik menyentuh secara positif, konstruktif, dan komprehensif aspek-aspek kemandirian/ kemanusiaan peserta didik.

Penerapan kewibawaan atau hightouch (selanjutnya dipakai istilah kewibawaan) untuk pengembangan kemandirian peserta didik meliputi: pengakuan dan penerimaan, kasih sayang dan kelembutan, penguatan, tindakan tegas yang mendidik, keteladanan dan pengarahan. Sedangkan Kewiyataan (hightech) adalah "alat pembelajaran" yang diselenggarakan pendidik untuk merealisasikan proses pencapaian tujuan pendidikan oleh peserta didik yang mengarah kepada penggunaan teknologi tinggi. Hightech Selanjutnya dipakai istilah (Kewiyataan) meliputi: materi pembelajaran, metode pembelajaran, alat bantu pembelajaran, lingkungan pembelajaran, dan penilaian hasil belajar. Proses pembelajaran seharusnya tidak hanya dilaksanakan dengan materi dan metode pelajaran yang tepat, tetapi juga searah dengan pengembangan sisi-sisi afektif dan sosial siswa guna mencapai tujuan pendidikan secara utuh. Kewibawaan dan Kewiyataan harus berjalan beriringan dalam rangka peningkatan mutu kegiatan dan hasil belajar siswa.

Moh. Ansyar mengemukakan bahwa mutu pendidikan pada dasarnya berasal dari terwujudnya kelas efektif yang harus ditunjang dengan adanya iklim sekolah yang memfasilitasi guru untuk menjadikan semua ruang kelas menjadi efektif. Kelas efektif tersebut ditandai dengan kewibawaan yang diaplikasikan guru melalui pemberdayaan siswa, berupa keterlibatan aktif mereka

3 Dasniwati, Hubungan Guru Siswa dan Keterkaitannya dengan Kegiatan Belajar Siswa: Studi pada Sekolah Dasar Negeri 03 Alai Kota Padang. Tesis; Program Pascasarjana Universitas Negeri Padang, 2007. 
pada setiap proses pembelajaran yang ditandai dengan kesenangan mereka melaksanakan kegiatan belajar di kelas. ${ }^{4}$

Hal senada dikemukakan oleh Prayitno bahwa peristiwa pendidikan hanya akan terjadi apabila situasi pendidikan tumbuh dan berkembang melalui teraktualisasinya kewibawaan yang salah satunya dapat tercermin melalui gaya yang ditampilkan guru dalam proses pembelajaran sebagai wahana relasi antara guru dengan siswa yang merupakan syarat terjadinya situasi pendidikan. Melalui gaya yang ditampilkan dalam proses pembelajaran, guru dapat menjamin kepastian untuk tumbuh kembangnya situasi pendidikan tersebut. ${ }^{5}$

Hasil observasi juga menunjukkan masih banyak kasus berkaitan dengan hubungan yang kurang serasi antara guru dengan siswa dalam proses pembelajaran yang justru bertentangan dengan makna dan tujuan pendidikan itu sendiri. Hal ini disebabkan gaya/penampilan guru dalam proses pembelajaran cenderung memosisikan siswa pada kedudukan yang inferior, pasif, guru lebih menunjukkan sikap defensif dan pembenaran, bahkan sampai perbuatan kekerasan fisik seperti menampar dan menendang siswa. Sehingga yang terjadi kemudian adalah kekerasan dalam sekolah (school violence) sebagaimana yang banyak terungkap akhir-akhir ini dalam media massa dan berbagai penelitian baik di sekolah-sekolah di dalam negeri maupun di luar negeri..

Berdasarkan berbagai permasalahan dan fenomena yang telah dipaparkan di atas, peneliti menduga kondisi ini berkaitan dengan tidak dilaksanakannya kewibawaan dan Kewiyataan dengan semestinya. Untuk itu perlu untuk diketahui gambaran secara jelas proses pembelajaran khususnya penerapan kewibawaan dan Kewiyataan dan keterkaitannya dengan mutu kegiatan dan hasil belajar siswa dengan melakukan penelitian dengan mengelompokkan sekolah berdasarkan perolehan UN dengan kategori sekolah tinggi, sedang dan rendah. Penelitian ini secara khusus dilaksanakan pada Sekolah Menengah Pertama (SMP) Negeri di Kabupaten Tanah Datar.

${ }^{4}$ Moh. Ansyar, Sekolah Efektif; Makalah. Disampaikan dalam Seminar Internasional FIP-JIP di Bukittinggi.Tgl 12 - 14 September 2005.

5 Prayitno, Hubungan Pendidikan, (Jakarta: Departemen Pendidikan Nasional Direktorat Jendral Pendidikan Dasar dan Menengah Direktorat SLTP, 2002), hlm. 53. 
Pemilihan lokasi ini selain didasarkan atas rendahnya perolehan UN dengan alokasi dana pendidikan yang tinggi, juga didasarkan pada adanya program BERMUTU (Better Education through Reform Management and Universal Teacher Upgrading) untuk lima Kabupaten seindonesia yang didanai oleh World Bank dan telah dilaksanakan sejak tahun 2005. Program ini merupakan Pilot Project untuk terlaksananya pendidikan yang lebih baik melalui reformasi manajemen dan peningkatan mutu guru. ${ }^{6}$

Berdasarkan latar belakang masalah, identifikasi dan pembatasan masalah di atas, maka masalah penelitian dapat dirumuskan dalam bentuk pertanyaan sebagai berikut: (1) Bagaimanakah kondisi kewibawaan, Kewiyataan menurut siswa, mutu kegiatan belajar siswa dan hasil belajar siswa? (2) Seberapa besar hubungan kewibawaan, Kewiyataan menurut siswa dan mutu kegiatan belajar siswa dengan hasil belajar siswa? (3) Apakah terdapat perbedaan hubungan kewibawaan, Kewiyataan menurut siswa dan mutu kegiatan belajar siswa dengan hasil belajar siswa pada sekolah kategori tinggi, sedang, dan rendah?

\section{B. Kajian Pustaka}

1. Kewibawaan

Pokja Pengembangan Peta Keilmuan Pendidikan mengemukakan bahwa high touch (kewibawaan) merupakan "alat pendidikan" yang diaplikasikan oleh guru untuk menjangkau (to touch) kemandirian siswa dalam hubungan pendidikan. Kewibawaan ini mengarah kepada kondisi hightouch, dalam arti perlakuan guru menyentuh secara positif, konstruktif, dan komprehensif aspek-aspek kemandirian/kemanusiaan siswa. Guru sebagai pelaksana proses pembelajaran seharusnya memiliki kualifikasi profesional, intelektual dan memiliki integritas moral yang tinggi sehingga guru memiliki modal yang cukup pada dirinya berupa penerapan kewibawaan tersebut, untuk

\footnotetext{
${ }^{6}$ Motoko Akiba, Student Victimization: National and School System Ef-
} fects on School Violence in 37 Nations. American Educational Research Journal Winter 2002, Vol. 39, page 829-853. Didownload dari http://aerj.aera.net at Institute of Education University of London on December 3, 2008. 
mengembangkan kemampuan dan potensi yang ada pada siswa. ${ }^{7}$

Sejalan dengan pendapat di atas, M. Dalyono mengemukakan proses pembelajaran merupakan kegiatan inti dalam proses pendidikan di mana guru dan siswa berinteraksi. Pendidikan pada hakikatnya adalah pelayanan bagi siswa. Agar pelayanan tersebut mengubah tingkah laku siswa ke arah perkembangan pribadi yang optimal, maka pelayanan itu hendaknya sesuai dengan sifat dan hakikat siswa. ${ }^{8}$ Sedangkan Abu Ahmadi dan Widodo Supriyono menyatakan bahwa hubungan guru dan siswa dalam proses pembelajaran yang diharapkan adalah hubungan manusiawi yang di dalamnya tercakup unsur-unsur kasih sayang dan pengarahan serta keteladanan. ${ }^{9}$

Dari beberapa pendapat di atas, dikemukakan bahwa untuk mencapai tujuan pembelajaran secara optimal, diperlukan adanya interaksi antara guru dan siswa dalam proses pembelajaran yang diwarnai dengan unsur-unsur penghargaan terhadap harkat martabat manusia baik bagi guru maupun siswa. Sejalan dengan hal ini pendapat yang dikemukakan oleh Prayitno menyatakan bahwa hubungan pendidikan tidak terjadi secara acak, akan tetapi tumbuh dan berkembang melalui teraktualisasikannya kewibawaan (hightouch), berupa pengakuan dan penerimaan, kasih sayang dan kelembutan, pengarahan, penguatan, tindakan tegas yang mendidik serta keteladanan di dalam relasi antara guru dan siswa. Lebih jauh, Prayitno menyatakan bahwa pada banyak kasus dapat diketahui bahwa hubungan yang terjadi di antara kedua belah pihak tersebut justru menimbulkan situasi yang bertentangan dengan makna dan tujuan pendidikan itu sendiri, seperti terjadinya pelecehan, penghinaan, persaingan, permusuhan dan sebagainya. Hubungan interaksi yang kondusif antara guru dengan siswa dalam proses pembelajaran harus diupayakan oleh guru melalui penerapan kewibawaan,

${ }^{7}$ Pokja Pengembangan Peta Keilmuan Pendidikan, Peta Keilmuan Pendidikan, Jakarta: Depdiknas Dirjen Dikti, 2005.

${ }^{8}$ M. Dalyono, Psikologi Pendidikan, (Jakarta: Rineka Cipta, 1997), hlm. 83 .

${ }^{9}$ Abu Ahmadi dan Widodo Supriyono. 1995. Psikologi Belajar. (Jakarta: Rineka Cipta, 2000), hlm. 32. 
sehingga suasana proses pembelajaran menjadi menyenangkan dan memungkinkan potensi siswa dapat berkembang secara lebih optimal. ${ }^{10}$

Sumadi Suryabrata menyatakan bahwa dalam proses pembelajaran, guru harus senantiasa mengembangkan potensi yang dimiliki siswa berupa potensi bakat, minat serta intelektual yang berbeda antara individu yang satu dengan individu yang lainnya dan kepribadian mereka yang unik dan khas. Pengembangan potensi siswa tersebut akan terwujud apabila guru mampu memberikan pengarahan, bimbingan dan model bagi siswa. ${ }^{11}$

Prayitno dan Wijaya dkk. menyatakan bahwa dalam proses pendidikan, kedekatan antara guru dan siswa serta hubungan antara guru dan siswa haruslah mengarah kepada tujuan-tujuan intrinsik pendidikan, dan terbebas dari tujuantujuan ekstrinsik yang bersifat pamrih untuk kepentingan pribadi guru. Pamrih-pamrih yang ada, selain dapat merugikan dan membebani siswa, merupakan pencederaan terhadap makna pendidikan dan menurunkan kewibawaan guru. ${ }^{12}$ Berkaitan dengan hal ini, Muhibbin menyatakan bahwa kewibawaan guru di mata murid kian jatuh. Murid-murid masa kini, khususnya yang menduduki sekolah-sekolah di kota pada umumnya hanya cenderung menghormati guru apabila ada maksud-maksud tertentu seperti untuk mendapatkan nilai tinggi dan dispensasi. Memang, guru diharapkan dapat memberikan bantuan kepada siswa. Bantuan tersebut lebih diutamakan yang bersifat sosial psikologis akademik; bukan material ekonomis fisik, Intensitas bantuan itu harus sesuai dengan kebutuhan dan kondisi siswa, tidak terkesan memanjakan (karena terlalu banyak) atau mengabaikan (karena terlalu sedikit). ${ }^{13}$

Hal-hal yang dikemukakan Prayitno berikut ini dapat merangkum hal-hal tersebut, yaitu bahwa unsur-unsur kewibawaan (hightouch) berupa pengakuan dan penerimaan,

${ }^{10}$ Prayitno, Hubungan Pendidikan ..., hlm. 54.

11 Sumadi Suryabrata, Psikologi pendidikan, (Jakarta: Rajawali1991), hlm. 24

${ }^{12}$ Hamka, Pribadi, (Jakarta: Bulan Bintang, 1950), hlm. 15.

${ }^{13}$ Muhibbin Sya, Psikologi dan Pendidikan dengan Pendekatan Baru, (Bandung: Rosda Karya 2003), 83. 
kasih sayang dan kelembutan, pengarahan, penguatan, tindakan tegas yang mendidik serta keteladanan dalam proses pembelajaran, dan esensi kewibawaan adalah kualitas pengakuan dan penerimaan guru yang dihayati oleh siswa, yang disertai oleh kasih sayang dan kelembutan, pengarahan, penguatan, dan tindakan tegas yang mendidik serta keteladanan dari guru. ${ }^{14}$

2. Kewiyataan

Mutu pendidikan juga akan terwujud apabila proses pembelajaran sebagai inti kegiatan pendidikan menerapkan Kewiyataan. Kewiyataan berasal dari kata "wiyata", yang dalam Kamus Besar Bahasa Indonesia didefinisikan sebagai pengajaran atau pelajaran. Kewiyataan dalam hal ini adalah isi atau kandungan pelajaran yang diberikan oleh guru. Lebih lanjut Prayitno berpendapat bahwa Kewiyataan perlu diselenggarakan guru untuk merealisasikan proses pencapaian tujuan pendidikan oleh siswa. Proses pencapaian tujuan ini mengarah kepada kondisi "high technology". Aspek ini merupakan sisi kegiatan pengajaran dalam keilmuan pendidikan yang meliputi: a) materi pembelajaran, b) metode, c) alat bantu pembelajaran, d) lingkungan pembelajaran, dan e) penilaian hasil pembelajaran.

3. Mutu kegiatan belajar siswa

Siswa akan memperoleh keberhasilan dalam belajarnya apabila ia melakukan kegiatan belajar dengan baik dan terhindar dari berbagai permasalahan yang dialaminya. Permasalahan di sini dapat dimaknai sebagai segala sesuatu yang dirasakan mengganggu individu dan menghambat pencapaian tujuan belajarnya.

Permasalahan dalam belajar seringkali tidak dapat dihindari oleh siswa. Dalam proses pembelajaran sehari-hari, siswa dapat mengalami berbagai permasalahan. Lebih lanjut Prayitno mengemukakan lima kondisi utama yang ada pada diri siswa yang secara langsung mempengaruhi mutu belajar siswa. Apabila lima kondisi utama tersebut tidak menjadi perhatian dapat mengakibatkan permasalahan bagi siswa.

14 Karakteristik Pendidik dalam Keilmuan Pendidikan, Laporan Penelitian Studi Pengembangan Aplikasi High-Touch dan High-Tech dalam Proses Pembelajaran Di Sekolah tahun 2005. Penelitian Hibah Pascasarjana. 
Kondisi tersebut adalah: Prasyarat penguasaan materi $(\mathrm{P})$, Keterampilan belajar (T), Sarana belajar (S), Keadaan diri pribadi (D), dan Lingkungan belajar dan sosio-emosional (L).

Keadaan PTSDL siswa akan menentukan mutu kegiatan belajar yang selanjutnya akan menentukan hasil belajar mereka.

Dalam kaitan itu, keadaan PTSDL siswa perlu diungkapkan dalam rangka peningkatannya demi pencapaian hasil belajar yang optimal. Pengungkapan masalah-masalah siswa dalam belajar khususnya siswa SLTP di kenal dengan alat ungkap masalah. ${ }^{15}$

4. Hasil Belajar Siswa

Teori Gagne tentang belajar (1977), Romizowski (1981) mengutarakan dua definisi belajar, yakni: (1) Belajar adalah suatu proses untuk memperoleh motivasi dalam pengetahuan, keterampilan, kebiasaan, tingkahlaku. (2) Belajar adalah penguasaan pengetahuan atau keterampilan yang diperoleh melalui proses interaksional. Selanjutnya Gagne menyatakan bahwa untuk mengenali apa yang dimaksud dengan belajar, maka dapat dilihat ciri-ciri penting belajar, yakni: (1) belajar adalah proses di mana manusia dapat melakukannya; (2) belajar umumnya melibatkan interaksi dengan lingkungan eksternal; dan (3) belajar terjadi bila suatu perubahan atau modifikasi perilaku terjadi, dan perubahan itu tetap dalam masa yang relatif lama pada kehidupan individu. Dari uraian ini dapat dipahami bahwa belajar mempunyai tujuan. Selanjutnya tujuan yang dimaksud ialah hasil belajar berupa penguasaan pengetahuan, keterampilan dan sikap atau tingkah laku yang diinginkan. ${ }^{16}$

Snellbecker (1974), Syaiful Bahri (1994), dan Nasrun Harahap dkk. (1979) mengidentifikasi perubahan tingkah laku yang diperoleh melalui belajar dapat dilihat pada ciri-ciri sebagai berikut: (a) terbentuknya tingkah laku yang baru berupa kemampuan aktual maupun potensial; (b) kemampuan

15 Prayitno dkk, Dasar Teori dan Praksis Pendidikan, (Padang: Pascasarjana. Universitas Negeri Padang, 2008), hlm. 67.

${ }^{16}$ Romizowski AJ. Gagne, Designing Instructional System, (New York: Nichols Publishing Company, 1981.), hlm 23. 
itu berlaku dalam waktu yang relatif lama; dan (c) kemampuan baru itu diperoleh melalui usaha. ${ }^{17}$

Tujuan pembelajaran merupakan hasil yang akan dicapai melalui proses belajar. Bloom mengemukakan taksonomi tujuan pembelajaran kepada tiga ranah (domain), yakni lapangan kognitif, afektif, dan psikomotor. Lapangan kognitif meliputi tujuan yang berhubungan dengan berpikir, mengetahui, dan memecahkan masalah. Lapangan afektif mencakup tujuan-tujuan yang berkaitan dengan sikap, nilai, minat, dan apresiasi. Lapangan psikomotor meliputi tujuantujuan yang berhubungan dengan keterampilan manual dan motorik. Selanjutnya Gagne (1977) membagi taksonomi tujuan yang merupakan hasil belajar yang akan dicapai kepada lima kategori, yakni: (1) informasi verbal, (2) kemampuan intelektual, (3) strategi kognitif, (4) keterampilan motorik, dan (5) sikap.

Tinggi rendahnya pencapaian hasil belajar siswa dipengaruhi oleh beberapa faktor. Faktor-faktor tersebut dapat berasal dari dalam diri siswa dan faktor yang berasal dari luar diri siswa. ${ }^{18}$ Yang termasuk faktor dalam diri adalah faktor kematangan, kecerdasan, motivasi, minat dan faktor pribadi. Faktor yang berasal dari luar diri siswa meliputi faktor lingkungan sosial, dan alat-alat yang digunakan dalam proses pembelajaran, penguasaan materi pokok pembelajaran maupun materi pendukung. Rendahnya keterampilan belajar siswa tersebut seringkali juga menyebabkan siswa mengalami banyak masalah terutama yang berkenaan dengan penguasaan materi pelajaran yang berujung kepada rendahnya hasil belajar yang dicapai siswa. ${ }^{19}$

Dari pendapat di atas, dapat disimpulkan bahwa proses dan hasil belajar siswa dipengaruhi oleh berbagai faktor baik

${ }^{17}$ Glenn E. Snellbecker, Learning Theory, Instructional Theory, and Psychoaducational Design, (New York: Mc. Graw-Hill Inc., 1974); Nasrun Harahap, dkk. Teknik Penilaian Hasil Belajar, (Jakarta: Bulan Bintang, 1994), hlm. 81.

18 Ngalim Purwanto M, Psikologi Pendidikan, (Bandung: Remaja Rosda Karya, 1986), hlm. 55.

${ }^{19}$ Gie.T.L, Cara Belajar yang Efisien: Sebuah Buku Pegangan untuk Mahasiswa Indonesia (1995). 
faktor internal dan faktor eksternal siswa serta penguasaan materi pokok dan materi pendukung.

5. Kondisi Kewibawaan, Kewiyataan menurut siswa, Mutu Kegiatan belajar siswa dan hasil belajar siswa.

a. Kondisi penerapan kewibawaan dalam proses pembelajaran

Gambaran kondisi kewibawaan yang mencakup pengakuan dan penerimaan, kasih sayang dan kelembutan, penguatan, tindakan tegas yang mendidik, keteladanan dan pengarahan secara keseluruhan dapat dilihat pada Gambar 1 berikut ini.

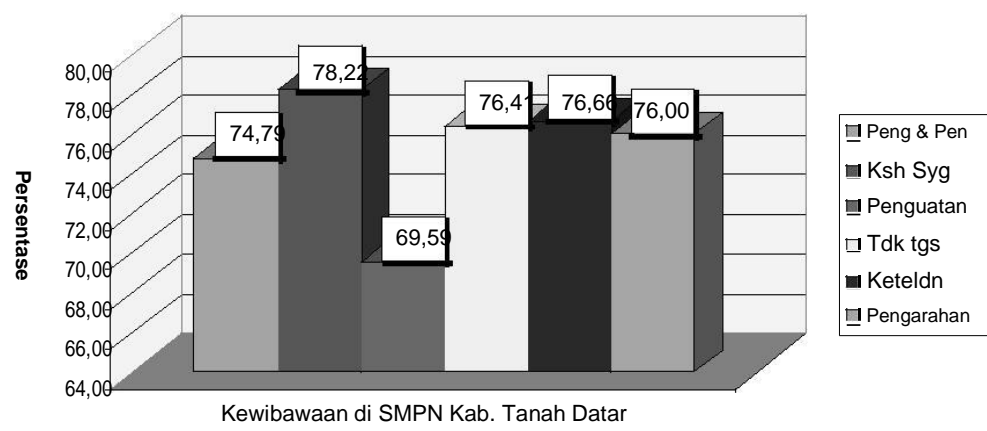

Gambar 1. Rata-Rata Persentase Penerapan Kewibawaan di SMP Negeri Kabupaten Tanah Datar

Gambar 1 mengungkapkan kondisi penerapan kewibawaan oleh guru dalam proses pembelajaran menurut siswa di SMP Negeri Kabupaten Tanah Datar. Dari data ini terungkap dengan jelas bahwa penerapan kewibawaan paling tinggi berada pada aspek kasih sayang dan kelembutan diikuti dengan keteladanan, tindakan tegas yang mendidik, pengakuan dan penerimaan, dan terendah adalah penguatan.

Apabila dianalisis secara lebih mendalam, ada beberapa kemungkinan yang menyebabkan rendahnya penerapan aspek penguatan dalam proses pembelajaran oleh guru. Pertama, kurangnya penerapan penguatan oleh guru dalam proses pembelajaran sangat mungkin 
disebabkan oleh karena kurangnya pemahaman guru terhadap arti pentingnya penguatan dalam proses pembelajaran. $^{20}$ Glover dan Roger, Child menyatakan bahwa reinforcement dan pemberian respons positif dan negatif atau reward dan punishment merupakan faktor yang penting dalam membangkitkan keterlibatan aktif siswa terhadap proses pembelajaran. ${ }^{21}$ Hal senada diungkapkan oleh Bandura bahwa dalam pembelajaran sosial, reinforcement yang diberikan kepada individu memegang fungsi penting yakni fungsi motivasi. ${ }^{22}$ Kurangnya pemahaman guru terhadap arti pentingnya penguatan terhadap keberhasilan belajarnya, menjadi penyebab rendahnya penerapan penguatan ini dalam proses pembelajaran. Kondisi ini tentu saja tidak boleh dibiarkan begitu saja apabila dikehendaki prestasi belajar siswa terus meningkat. Diperlukan pemahaman yang baik dari para guru terkait arti pentingnya penguatan terhadap upaya peningkatan hasil belajar siswa.

Kedua, rendahnya penerapan guru terhadap aspek penguatan dalam proses pembelajaran juga dimungkinkan karena kekurangan tahuan guru terhadap bentuk dan cara dalam pemberian penguatan kepada siswa. Keterampilan guru dalam menguasai bagaimana teknik memberikan penguatan walau dengan cara yang paling sederhana misalnya dengan sebuah anggukan, diduga juga menjadi penyebab rendahnya penerapan aspek penguatan dalam proses pembelajaran. Kondisi ini tentu saja memerlukan penyelesaian dengan cara memberikan pemahaman dan keterampilan kepada guru agar mereka memiliki wawasan dan pengetahuan yang luas terhadap pentingnya aspek penguatan dan mampu menerapkannya dalam proses pembelajaran.

${ }^{20}$ Glover John A and Roger H Bruning, Educational Psychology Principles and Applications, (United States of America: Harper Collins Publishers, 1990), hlm. 33.

${ }^{21}$ Dennis Child, Psychology and the Teacher, (New York: Continuum, 2007), hlm. 59.

${ }^{22}$ Bandura Albert, Social Learning Theory. Englewood Cliffs, (New Jersey: Prentice-Hall Inc, 1977), hlm. 55. 
b. Kondisi penerapan Kewiyataan dalam proses pembelajaran

Gambaran secara jelas penerapan Kewiyataan dalam proses pembelajaran di SMPN Kabupaten Tanah Datar menyangkut materi pembelajaran, metode pembelajaran, alat Bantu pembelajaran, lingkungan pembelajaran dan penilaian pembelajaran dapat dilihat pada Gambar 2.

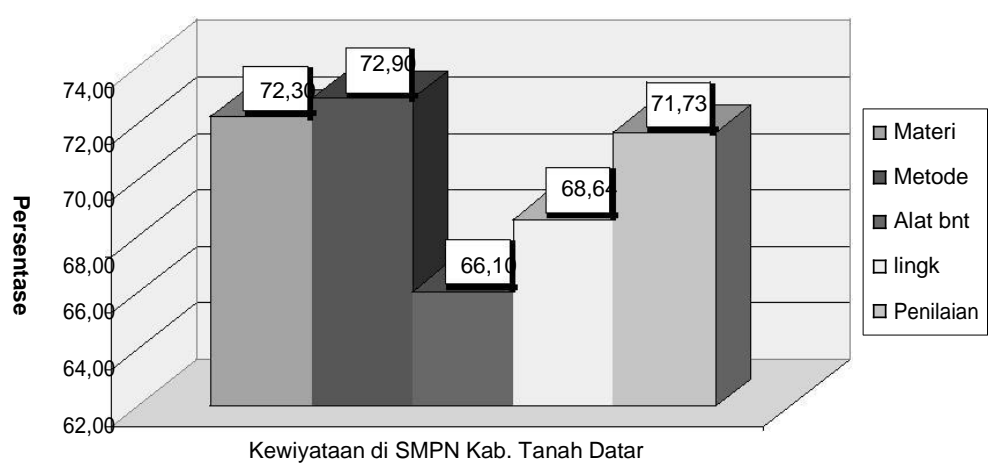

Gambar 2. Rata-Rata Persentase Penerapan Kewiyataan di SMP Negeri Kabupaten Tanah Datar

Gambar 2 mengungkapkan kondisi penerapan Kewiyataan oleh guru dalam proses pembelajaran menurut siswa di SMP Negeri Kabupaten Tanah Datar. Dari data ini terungkap dengan jelas bahwa penerapan Kewiyataan paling tinggi berada pada indikator metode pembelajaran diikuti dengan materi pembelajaran, penilaian hasil pembelajaran, lingkungan pembelajaran dan terendah pada indikator alat Bantu pembelajaran.

Penerapan Kewiyataan pada aspek alat bantu dan lingkungan pembelajaran paling rendah dibandingkan dengan aspek-aspek Kewiyataan yang lain. ${ }^{23}$ Fakta ini ditemui di ketiga sekolah sampel penelitian yaitu di SMPN 1 Batusangkar, SMPN 1 X Koto dan SMPN 2 X Koto. Azhar, dan Yusufhadi menyatakan bahwa perlu disediakan sarana dan prasarana yang memadai terutama sarana dan

${ }^{23}$ Azhar Arsyad, Media Pembelajaran, (Jakarta: Raja Grafindo Persada, 2004), hlm. 101. 
prasarana yang berkaitan langsung dengan proses pembelajaran bagi siswa untuk memenuhi kebutuhan belajar, menyalurkan minat dan bakat baik dalam kegiatan kurikuler maupun ekstrakurikuler. ${ }^{24}$

Kurangnya penekanan guru pada penerapan aspek media pembelajaran, sangat dimungkinkan karena pemahaman dan keterampilan guru yang kurang baik terhadap arti pentingnya media dalam proses pembelajaran dan bagaimana membuatnya. Padahal alat bantu pembelajaran sangat penting karena alat bantu yang tepat dan dapat membangkitkan kreativitas siswa harus dipilih dengan memperhatikan berbagai hal sebagaimana dikemukakan oleh Ngalim Purwanto pada pembahasan sebelumnya bahwa dalam memilih alat bantu pembelajaran yang baik dan sesuai hendaklah memperhatikan hal-hal sebagai berikut: a) tujuan yang hendak dicapai, b) siapa (guru) yang akan menggunakan alat tersebut, c) siswa yang akan dikenai alat dan d) bagaimana cara menggunakan alat tersebut. ${ }^{25}$ Demikian pentingnya ketersediaan alat bantu pembelajaran dalam menunjang kreativitas dan keberhasilan belajar siswa, sekolah dituntut untuk menyediakan berbagai fasilitas khususnya media yang diperlukan dalam proses pembelajaran. Demikian juga halnya dengan guru. Guru harus mengupayakan pengadaan dan penguasaan media pembelajaran sehingga hasil proses pembelajaran dapat lebih maksimal.

c. Kondisi mutu kegiatan belajar siswa

Secara keseluruhan, rata-rata skor kegiatan belajar di ke tiga sampel penelitian yaitu di SMPN 1 Batusangkar, SMPN 1 X Koto dan SMPN 2 X Koto adalah sebagaimana gambar berikut:

${ }^{24}$ Yusufhadi Miarso, Menyemai Benih Teknologi Pendidikan, (Jakarta: Prenada Media, 2004), hlm. 43.

${ }^{25}$ Ngalim Purwanto M, 1986, Psikologi Pendidikan ..., hlm. 55. 


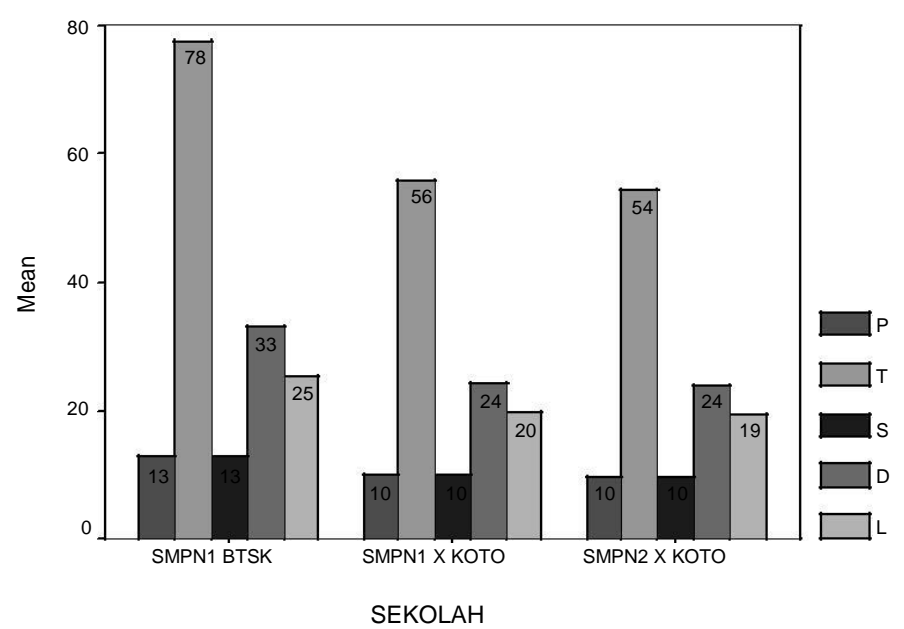

Gambar 3. Rata-rata Skor Kegiatan Belajar

Berdasarkan Gambar 3 dapat dikemukakan bahwa rata-rata skor kegiatan belajar siswa di ke tiga sekolah sampel penelitian masih belum memadai. Hal ini terjadi pada keseluruhan masing-masing aspek penguasaan materi pelajaran, keterampilan belajar, sarana prasarana, diri pribadi dan lingkungan fisik sosioemosional.

Rendahnya skor kegiatan belajar siswa apabila dianalisa secara lebih mendalam dapat dikemukakan bahwa, memang seringkali rendahnya penguasaan siswa atas materi pelajaran baru bukan disebabkan karena kemampuan dasar atau kecerdasan siswa, tetapi disebabkan oleh penguasaan materi yang menjadi prasyarat untuk menguasai materi selanjutnya masih kurang. Oleh karena itu, guru harus selalu memperhatikan penguasaan siswa terutama pada aspek ketuntasan dalam penyampaian materi pelajaran.

Kondisi temuan penelitian terkait dengan prasyarat penguasaan materi pelajaran tersebut di atas sejalan dengan pendapat Depdiknas yang menengarai kurangnya penguasaan siswa terhadap materi pelajaran baru yang diberikan guru antara lain disebabkan oleh kurangnya penguasaan siswa terhadap materi sebelumnya. Materi itu menjadi prasyarat bagi siswa untuk menguasai materi pelajaran baru. Penguasaan materi pelajaran sebelumnya 
merupakan modal utama peningkatan mutu kegiatan belajar siswa.

d. Kondisi Hasil Belajar Siswa SMPN Kabupaten Tanah Datar

Gambaran rata-rata hasil belajar siswa SMPN Kabupaten Tanah Datar secara keseluruhan yang terdiri dari mata pelajaran Bahasa Indonesia, Bahasa Inggris, IPA dan Matematika dapat dilihat pada Gambar 4 :

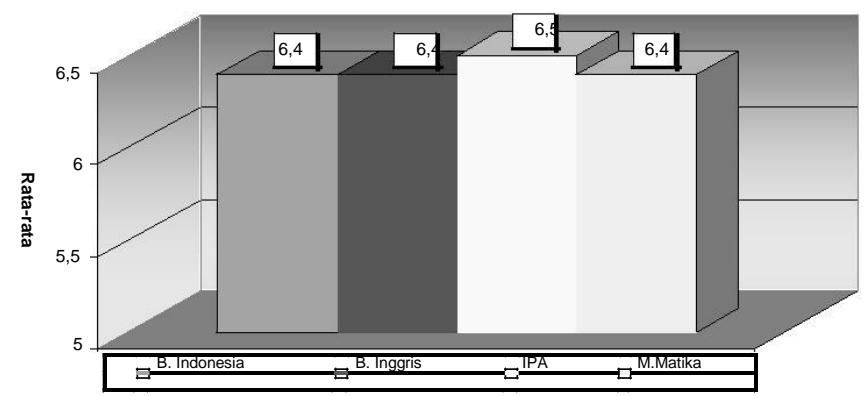

Gambar 4. Rata-rata Hasil Belajar Siswa SMPN Kabupaten Tanah Datar

Gambar 4 menunjukkan gambaran rata-rata hasil belajar siswa SMPN Kabupaten Tanah Datar pada empat bidang studi yang menjadi UN yaitu B.Indonesia, Bahasa Inggris, IPA dan Matematika. Data ini memperlihatkan bahwa rata-rata empat bidang studi hasil belajar siswa memiliki rata-rata hampir sama. Data ini juga tidak jauh berbeda dengan data rata-rata hasil UN 2006/2007, dan 2007/ 2008 yang telah disebutkan pada latar belakang masalah.

Berdasarkan paparan hasil temuan penelitian tersebut dapat dikemukakan analisis bahwa, adanya kecenderungan hasil belajar siswa yang lebih baik pada sekolah yang masuk pada kriteria tinggi dibandingkan dengan sekolah yang masuk kriteria sedang dan rendah sangat dimungkinkan terjadi. Hal ini berdasarkan asumsi dan teori yang telah dikemukakan pada bab sebelumnya bahwa tinggi rendahnya pencapaian hasil belajar siswa dipengaruhi oleh beberapa faktor. Faktor-faktor tersebut 
menurut Ngalim Purwanto dapat berasal dari dalam diri siswa dan faktor yang berasal dari luar diri siswa. Yang termasuk faktor dalam diri adalah faktor kematangan, kecerdasan, motivasi, minat dan faktor pribadi. Faktor yang berasal dari luar diri siswa meliputi faktor lingkungan sosial, dan alat-alat yang digunakan dalam proses pembelajaran.

Kondisi temuan penelitian dan analisis sebagaimana telah dipaparkan di atas, menuntut adanya pemahaman yang lebih baik dari para guru terutama dalam upaya meningkatkan hasil belajar pada semua jenis atau jenjang sekolah tanpa harus melihat kriteria sekolah terutama melalui peningkatan mutu kegiatan belajar dan penerapan Kewiyataan dan kewibawaan dalam proses pembelajaran.

6. Hubungan Variabel Kewibawaan, Kewiyataan dan Mutu Kegiatan Belajar Siswa dengan Hasil Belajar Siswa

Analisis yang digunakan untuk point 2 ini menggunakan Struktural Equation Modeling (SEM) Hasil analisis dengan menggunakan Lisrel dapat dilihat pada Gambar 5.

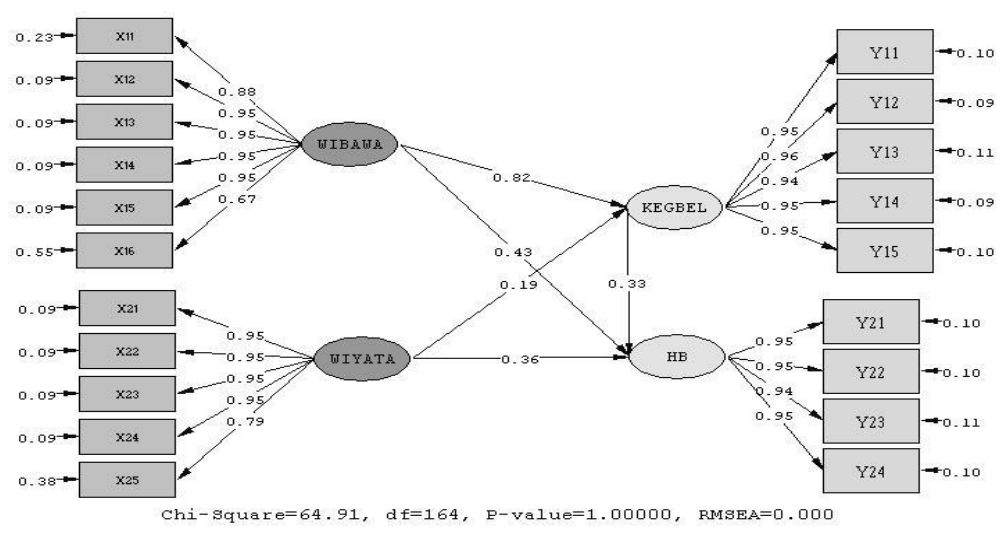

Gambar 4. Standar Solution (1) dan T-Value (2) Parameter Estimasi Hubungan antara Penerapan Kewibawaan dan Kewiyataan dengan Mutu Kegiatan Belajar dan Hasil Belajar Siswa. 


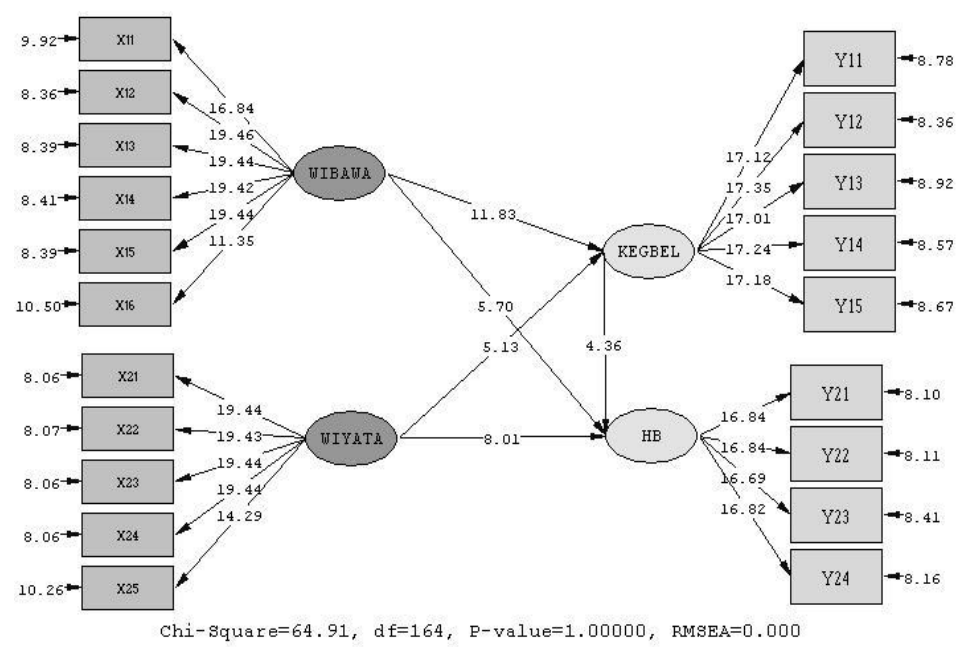

a. Hubungan Variabel Kewibawaan, Kewiyataan dengan mutu Kegiatan Belajar Siswa

Rangkuman hasil analisis data menghasilkan persamaan sebagai berikut:

MUTUKEGBEL $=0.82 *$ WIBAWA $+0.19 *$ WIYATA, Errorvar

$$
\begin{aligned}
= & 0.23, \mathrm{R}^{2} \\
= & 0.77(0.069)(0.038) \\
& 11.835 .13
\end{aligned}
$$

Persamaan ini menunjukkan besarnya hubungan variabel kewibawaan dan variabel Kewiyataan terhadap mutu kegiatan belajar siswa masing-masing sebesar 0,82 dan 0,19 dengan nilai kesalahan standar dan Tvalue masing-masing sebesar 0,$069 ; 11,83$ dan 0,$038 ; 5,13$, hal ini menunjukkan bahwa hubungan Kewiyataan dan kewibawaan terhadap Kegiatan belajar siswa adalah signifikan (Tvalue > 1,96). Secara bersama besarnya pengaruh kewibawaan dan Kewiyataan terhadap mutu kegiatan belajar siswa adalah $\left(\mathrm{R}^{2}=0,77 \times 100\right)=77 \%$ dan sisanya sebesar 0,23 merupakan pengaruh variabel 
lain (errorvar) yang tidak dijelaskan dalam analisis penelitian ini.

Melalui penerapan kewibawaan dalam proses pembelajaran, maka mutu kegiatan belajar akan meningkat dan masalah belajar yang dialami siswa akan menurun. Kewibawaan guru dalam proses pembelajaran dalam upaya peningkatan mutu pembelajaran dapat diwujudkan dalam berbagai bentuk. Bentuk yang pertama adalah memberikan keteladanan kepada siswa. Hal ini sejalan dengan pendapat Hadi Supeno, guru harus menjadi suri teladan di kelas dan di luar kelas, baik dalam hal kemampuan berpikir, bersikap, maupun bertutur kata yang tercermin dari tingkah lakunya. ${ }^{26}$

b. Hubungan Kewibawaan, Kewiyataan dan Mutu Kegiatan Belajar Siswa dengan Hasil Belajar Siswa.

Rangkuman hasil analisis data menghasilkan persamaan sebagai berikut:

$$
\begin{aligned}
\text { HB }(\text { ETA2 })= & 0.33 * \text { KEGBEL + 0.43*WIBAWA + } \\
& 0.35^{*} \text { WIYATA, Errorvar. } \\
= & 0.19, \mathrm{R}^{2} \\
= & 0.81(0.076)(0.075)(0.044) \\
& 4.36 \quad 5.708 .01
\end{aligned}
$$

Persamaan ini menunjukkan besarnya hubungan variabel mutu kegiatan belajar siswa, variabel kewibawaan dan variabel Kewiyataan dengan hasil belajar siswa masing-masing sebesar 0,33; 0,43 dan 0,35 dengan kesalahan standar dan Tvalue masing-masing sebesar 0,076;4,36, 0,075;5,70, dan 0,044;8,01. Data ini menunjukkan bahwa hubungan mutu kegiatan belajar, kewibawaan dan Kewiyataan terhadap hasil belajar siswa adalah signifikan (Tvalue > 1,96). Secara bersama-sama besarnya pengaruh ketiga variabel ini adalah $R^{2}=0,81$ dan sisanya sebesar 0,19 merupakan pengaruh variabel lain (errorvar) yang tidak dijelaskan oleh penelitian ini.

${ }^{26}$ Hadi Supeno, Reformasi Pendidikan, (Jakarta: Pustaka Paramedia, 1999), hlm. 34. 
Analisis ini membuktikan bahwa Kewibawaan berhubungan secara signifikan sebesar 0,43, Kewiyataan berhubungan secara signifikan sebesar 0,35 dan mutu kegiatan belajar siswa berhubungan secara signifikan sebesar 0,33 dengan hasil belajar siswa. Sedangkan pengaruh ketiga variabel ini dengan hasil belajar siswa sebesar $\mathrm{R}^{2}=0,81$ atau berkontribusi sebesar $81 \%$.

Berdasarkan data hasil penelitian ini, secara jelas dapat dikemukakan bahwa ada keterkaitan yang erat dan signifikan antara indikator-indikator kewibawaan dan Kewiyataan dengan mutu kegiatan belajar siswa dan hasil belajar siswa. Hal ini dapat digunakan sebagai bukti kebenaran asumsi yang dikemukakan sebelumnya bahwa tinggi rendahnya hasil belajar siswa dikarenakan adanya penerapan kewibawaan dan Kewiyataan dalam proses pembelajaran dan kualitas atau mutu kegiatan belajar siswa.

7. Perbedaan Hubungan Kewibawaan, Kewiyataan Menurut Siswa dan Mutu Kegiatan Belajar Siswa dengan Hasil Belajar Mereka pada Sekolah Kategori Tinggi, Sedang, dan Rendah

Berdasarkan hasil analisis yang dilakukan dengan menggunakan program Lisrel didapat angka korelasi sebagai mana terlihat pada Tabel 1 berikut.

Tabel. 1 Rangkuman Hasil Analisis Hubungan antar variabel Kewiyataan, Kewibawaan dan Mutu Kegiatan Belajar dengan Hasil Belajar Siswa

\begin{tabular}{|c|l|c|c|c|}
\hline N0 & $\begin{array}{l}\text { Hubungan antar } \\
\text { variabel }\end{array}$ & $\begin{array}{c}\text { SMPN 1 } \\
\text { Btskr }\end{array}$ & $\begin{array}{c}\text { SMPN 1 X Koto } \\
\text { Koto }\end{array}$ \\
\hline 1. & $\begin{array}{l}\text { Wibawa dgn mutu } \\
\text { belajar }\end{array}$ & 0,84 & 0,96 & 0,70 \\
\hline 2. & $\begin{array}{l}\text { Wibawa dgn hasil } \\
\text { belajar }\end{array}$ & 0,53 & 0,14 & 0,56 \\
\hline 3. & $\begin{array}{l}\text { Wiyata dng mutu } \\
\text { belajar }\end{array}$ & 0,38 & - & 0,26 \\
\hline 4. & $\begin{array}{l}\text { Wiyata dgn hasil } \\
\text { belajar }\end{array}$ & 0,19 & 0,62 & - \\
\hline
\end{tabular}




\begin{tabular}{|c|c|c|c|c|}
\hline & $\begin{array}{l}\text { Mutu belajar dng } \\
\text { hasil belajar }\end{array}$ & 0,44 & 0,61 & 0,32 \\
\hline 6. & Wibawa dgn Wiyata & 0,33 & - & 0,40 \\
\hline \multicolumn{2}{|c|}{$\begin{array}{l}\text { Koefisien Determinasi } \\
\left(\mathbf{R}^{2}\right)\end{array}$} & $0,79(79 \%)$ & $0,80(80 \%)$ & $0,62(62 \%)$ \\
\hline & & $\begin{aligned} P \text {-Value } & =1,00 \\
\text { RMSEA } & =0,00\end{aligned}$ & $\begin{array}{l}P-\text { Value }= \\
0.00033\end{array}$ & $\begin{array}{l}P-\text { Value }= \\
0.999\end{array}$ \\
\hline
\end{tabular}

\begin{tabular}{|c|c|c|c|}
\hline Ukuran Goodness of Fit & $\begin{array}{l}G F I=0,93 \\
A G F I=0,91 \\
C F I=1,00 \\
N F I=0,91\end{array}$ & $\begin{array}{l}\text { RMSEA }=0.080 \\
G F I=0.74 \\
A G F I=0.67 \\
C F I=0.95 \\
N F I=0.91\end{array}$ & $\begin{array}{l}\text { RMSEA } \\
=0.000 \\
G F I=0.89 \\
A G F I=0.85 \\
C F I=1.00 \\
N F I=0.95\end{array}$ \\
\hline Keterangan & $\begin{array}{l}\text { Model fit } \\
\text { dengan Data }\end{array}$ & $\begin{array}{l}\text { Model tidak fit } \\
\text { dengan data }\end{array}$ & $\begin{array}{l}\text { Model tidak fit } \\
\text { dengan data }\end{array}$ \\
\hline
\end{tabular}

Hubungan atau korelasi terbesar antara kewibawaan dengan mutu belajar siswa terjadi pada SMPN 1 X Koto diikuti dengan SMPN 1 Batusangkar dan SMPN 2 Koto dengan korelasi masing-masing sebesar 0,96; 0,84 dan 0,70 dan semuanya signifikan. Namun bila dilihat dari kesesuaian model, model yang paling baik dan dapat meramalkan atau digunakan untuk memprediksi adalah model pertama yakni pada SMPN 1 Batusangkar. Kontribusi terbesar antara kewibawaan, Kewiyataan dan mutu kegiatan belajar siswa dengan hasil belajar siswa secara bersama-sama berada pada SMPN $1 \mathrm{X}$ Koto sebesar 80\%, diikuti dengan SMPN 1 Batusangkar sebesar 79\% dan SMPN 2 X Koto sebesar 62\%.

Model atau kerangka konseptual yang diajukan untuk memprediksi hasil belajar pada SMPN 1 X Koto kurang efektif dalam memprediksi hasil belajar siswa walaupun disatu sisi kontribusi kewibawaan, Kewiyataan dan mutu kegiatan belajar siswa terhadap hasil belajar siswa paling besar mencapai $80 \%$. Kewiyataan dalam proses pembelajaran pada model ini tidak memiliki hubungan yang signifikan terhadap hasil mutu kegiatan belajar. Padahal penerapan Kewiyataan dalam proses pembelajaran harus mampu merubah prilaku 
kegiatan belajar siswa menjadi lebih baik. Sehingga dengan mutu belajar yang tinggi semakin kecil gangguan belajar mereka.

Kurang efektifnya model yang diajukan untuk memprediksi hasil belajar siswa dikarenakan beberapa hal. Pertama karena lingkungan pembelajaran kurang mendukung karena letaknya di pinggir jalan besar atau terletak di perlintasan jalan antar provinsi di mana sedikit banyaknya mengganggu konsentrasi belajar. Penyebab lainnya adalah ukuran kelas yang kecil atau tidak standar tetapi diisi dengan siswa yang banyak atau diistilahkan dengan kelas gemuk sehingga perhatian guru terutama dalam memperhatikan prasyarat penguasaan materi dan keterampilan belajar siswa kurang diperhatikan dan siswa sendiri tidak nyaman belajar dengan kondisi lingkungan seperti ini.

Sedangkan pada SMPN 2 X Koto terlihat bahwa Kewiyataan, kewibawaan dan mutu kegiatan belajar siswa terhadap hasil belajar siswa kontribusinya paling kecil dibanding dua sekolah lainnya. Hal ini menunjukkan bahwa dalam proses pembelajaran unsur kewibawaan dan Kewiyataan belum dilaksanakan secara maksimal oleh guru terutama pada aspek keteladanan dan lingkungan pembelajaran sehingga mempengaruhi aspek lainnya dalam meningkatkan hasil belajar siswa. Berdasarkan kondisi yang ada, SMPN 2 X Koto termasuk sekolah yang memiliki fasilitas lebih sedikit dibandingkan dengan dua sekolah yang diteliti. Namun untuk memprediksi hasil belajar siswa, model atau kerangka konseptual yang diusulkan terlihat lebih baik dibandingkan dengan SMPN 1 X Koto. Hal ini terlihat dari hubungan yang hampir seluruhnya signifikan kecuali hubungan Kewiyataan dengan hasil belajar siswa secara langsung. Kewiyataan lebih berpengaruh terhadap mutu kegiatan belajar siswa terlebih dahulu baru pada gilirannya mempengaruhi hasil belajar siswa. Hasil temuan ini mengindikasikan bahwa Kewiyataan dalam proses pembelajaran belum berjalan dengan baik. Kondisi ini diperkirakan disebabkan masih banyak guru $( \pm 35 \%)$ di sekolah ini belum memiliki kualifikasi pendidikan $\mathrm{S} 1$. 


\section{Kesimpulan}

Berdasarkan hasil penelitian dan pembahasan, dapat dikemukakan kesimpulan bahwa penerapan kewibawaan dalam proses pembelajaran tertinggi berada pada aspek kasih sayang dan kelembutan kemudian diikuti dengan keteladanan, tindakan tegas yang mendidik dan pengarahan. Penerapan aspek penguatan guru terhadap siswa paling rendah di antara aspek-aspek kewibawaan yang lain. Guru dalam proses pembelajaran kurang dapat memberikan penguatan dalam hal pemberian pujian, penghargaan, dorongan untuk berbuat baik dan hadiah.

Penerapan kewibawaan dalam proses pembelajaran paling tinggi berada pada aspek metode pembelajaran. Hal ini berarti guru sudah berusaha menerapkan metode yang bervariasi dalam mengajar seperti menggunakan metode diskusi, tanya jawab, metode percobaan dan bermain peran. Penguasaan materi pembelajaran dan penilaian juga merupakan aspek yang sudah diterapkan lebih baik dari aspek alat bantu pembelajaran dan lingkungan pembelajaran. Hal ini menunjukkan bahwa penguasaan guru terhadap materi dan cara guru menilai sudah tepat namun masih perlu ditingkatkan. Penggunaan alat bantu dan pengaturan lingkungan pembelajaran belum terlaksana dengan baik dalam proses pembelajaran karena masih terbatasnya media yang ada di sekolah. Sedangkan lingkungan pembelajaran menyangkut suasana, kenyamanan, luas kelas dan fasilitas perabot masih perlu ditambah dan diperbaiki.

Mutu kegiatan belajar siswa masih belum maksimal pada seluruh aspeknya yang mencakup prasyarat penguasaan materi pelajaran, keterampilan belajar, sarana prasarana belajar, diri pribadi dan lingkungan fisik sosioemosional pada masing-masing sekolah dan tingkatan kelas. Aspek tertinggi berada pada keterampilan belajar dalam hal membaca pelajaran, membuat catatan, cara bertanya, dan belajar bersama. Sedangkan aspek terendah berada pada prasyarat penguasaan materi dan sarana belajar.

Rata-rata hasil belajar siswa pada mata pelajaran Bahasa Indonesia 6,4, Bahasa Inggris 6,4, IPA 6,5 dan Matematika 6,4. Walaupun rata-rata ini sudah lebih besar dari target ketuntasan minimal dan kelulusan UN, tetapi rata-rata nilai ini masih perlu ditingkatkan. Ratarata hasil belajar siswa pada sekolah kategori 
tinggi lebih baik dari pada hasil belajar siswa pada sekolah kategori sedang dan rendah.

Kewibawaan dan Kewiyataan berhubungan secara signifikan terhadap mutu kegiatan belajar siswa. Besar koefisien determinasi kewibawaan dan Kewiyataan terhadap mutu kegiatan belajar siswa $\left(\mathrm{R}^{2}\right)=0,77$. Kewiyataan dan kewibawaan berpengaruh sebesar $77,0 \%$ terhadap mutu kegiatan belajar siswa dan sisanya sebesar $23, \%$ berasal dari faktor lain. Hal ini menunjukkan bahwa tinggi rendahnya mutu kegiatan belajar siswa ditentukan oleh sejauh mana faktor kewibawaan dan Kewiyataan diimplementasikan oleh guru dalam proses pembelajaran. Semakin baik penerapan kewibawaan dan Kewiyataan dalam proses pembelajaran maka mutu kegiatan belajar siswa akan semakin baik.

Kewibawaan, Kewiyataan dan mutu kegiatan belajar siswa berhubungan secara signifikan terhadap hasil belajar siswa. Besar koefisien determinasi kewibawaan, Kewiyataan dan mutu kegiatan belajar terhadap hasil belajar siswa $\left(\mathrm{R}^{2}\right)=0,81$. Kewiyataan, kewibawaan dan mutu kegiatan belajar berpengaruh sebesar $81,0 \%$ terhadap hasil belajar siswa dan sisanya sebesar $19,0 \%$ berasal dari faktor lain. Hal ini menunjukkan bahwa tinggi rendahnya hasil belajar siswa ditentukan oleh tinggi rendahnya penerapan kewibawaan dan Kewiyataan dalam proses pembelajaran oleh guru serta mutu kegiatan belajar siswa. Semakin baik penerapan kewibawaan, dan Kewiyataan dalam proses pembelajaran dan semakin tinggi mutu kegiatan belajar siswa maka hasil belajar siswa akan semakin tinggi.

Hubungan kewibawaan dan Kewiyataan untuk memprediksi mutu kegiatan belajar siswa dan hasil belajar siswa lebih baik pada sekolah kategori tinggi diikuti dengan sekolah kategori rendah dan sedang. Kontribusi kewibawaan, Kewiyataan dan mutu kegiatan belajar siswa terhadap hasil belajar siswa lebih besar pada sekolah kategori sedang dibandingkan dengan sekolah kategori tinggi dan rendah. Hubungan kewibawaan, Kewiyataan, dan mutu kegiatan belajar siswa berbeda secara nyata dalam memprediksi hasil belajar siswa.

\section{Kepustakaan}

Ahmadi, Abu dan Widodo Supriyono. 1995. Psikologi Belajar. Jakarta: Rineka Cipta. 
Akiba, Motoko. 2002. Student Victimization: National and School System Effects on School Violence in 37 Nations. American Educational Research Journal Winter 2002, Vol. 39, No. 4, pp. 829- 853. Downloaded from http://aerj.aera.net at Institute of Education University of London on December 3, 2008.

Ansyar, Mohd.. 2005. Sekolah Efektif. Makalah. Disampaikan dalam Seminar Internasional FIPJIP di Bukittinggi.Tgl 12 14 september.

Arsyad, Azhar. 2004. Media Pembelajaran. Jakarta: Raja Grafindo Persada.

Bandura, Albert. 1977. Social Learning Theory. Englewood Cliffs. New Jersey: PrenticeHall, Inc.

Child, Dennis. 2007. Psychology and The Teacher. New York: Continuum.

Dasniwati. 2007. Hubungan Guru Siswa dan Keterkaitannya dengan Kegiatan Belajar Siswa: Studi pada Sekolah Dasar Negeri 03 Alai Kota Padang. Tesis. Program Pascasarjana Universitas Negeri Padang.

Depdiknas. 2004. Konsep Pendidikan Kecakapan Hidup. Jakarta: Dirjen Dikdasmen.

Djamarah, Syaiful Bahri. 1994. Prestasi Belajar dan Kompetensi Guru. Surabaya. Usaha Nasional.

Gagne. 1997. The Conditions of Learning. New York: Holt, Rinehart and Winston.

Gie.T.L 1995. Cara Belajar yang Efisien: Sebuah Buku Pegangan untuk Mahasiswa Indonesia ( jilid II) Yogyakarta: Liberty.

Glover, John A and Roger H Bruning. 1990. Educational Psychology Principles and Applications. United States of America: Harper Collins Publishers. Jakarta: Bulan Bintang.

M. Dalyono. 1997. Psikologi Pendidikan. Jakarta: Rineka Cipta.

Makmur Tarihoran. 2006. Interaksi Sosial Siswa di Sekolah Menengah Kejuruan Penerbangan Angkasa Nasional Lanud Padang. Tesis. Program Pascasarjana Universitas

Miarso, Yusufhadi. 2004. Menyemai Benih Teknologi Pendidikan. Jakarta: Prenada Media. 
Nasution. S. 1988. Kurikulum dan Pengajaran. Jakarta: Bina Aksara.

-----. 1994. Berbagai Pendekatan dalam Proses Belajar dan Mengajar. Jakarta: Bina Aksara.

-----. 2003. Berbagai pendekatan dalam proses belajar \& mengajar. Jakarta. Bumi Aksara.

Ngalim, Purwanto M. 1986. Psikologi Pendidikan. Bandung: Remaja Rosda Karya.

-----. 2000. Ilmu Pendidikan Teoritis dan Praktis. Bandung: Remaja Rosda Karya.

-----. 2000. Psikologi Belajar dan Mengajar. Bandung: Sinar Baru Algensindo.

Pokja Pengembangan Peta Keilmuan Pendidikan. 2005. Peta Keilmuan Pendidikan. Jakarta: Depdiknas Dirjen Dikti.

Prayitno. 2002. Hubungan Pendidikan. Jakarta: Departemen Pendidikan Nasional Direktorat Jendral Pendidikan Dasar dan Menengah Direktorat SLTP.

------. 2005. Karakteristik Pendidik dalam Keilmuan Pendidikan. Laporan Penelitian Studi Pengembangan Aplikasi HighTouch dan HighTech dalam Proses Pembelajaran Di Sekolah. Penelitian Hibah Pascasarjana Tahun Pertama.

-----. 2005. Sosok Keilmuan Ilmu Pendidikan. Padang: Fakultas Ilmu Pendidikan UNP.

-----. 2008. Dasar Teori dan Praksis Pendidikan. Padang: UNP Press. Pascasarjana. Universitas Negeri Padang.

-----. 2009. Pendidikan : Dasar Teori dan Praksis. Padang: UNP Press. Pascasarjana. Universitas Negeri Padang.

Romizowski A. 1981. Designing Instructional System. New York: Nichols Publishing Company.

Skiba, Rusell, Gale Morrison, Michael Furlong, dan Dewey Gene Cornell. 2004. Issues in School Violence Research. New York: Routledge.

Supeno, Hadi. 1999. Reformasi Pendidikan. Jakarta: Pustaka Paramedia, Hamka. 1950. Pribadi. Jakarta: Bulan Bintang.

Suryabrata, Sumadi. 1991. Psikologi pendidikan. Jakarta: Rajawali. 
Syah, Muhibbin. 2003. Psikologi dan Pendidikan dengan Pendekatan Baru. Bandung: Rosda Karya.

Wijaya dan Tabrani Rusyan A. 1999. Kemampuan Dasar Guru dalam Proses Belajar dan Mengajar. Bandung : Remaja Rosda Karya.

Yusri. 2006. Proses Pembelajaran dan Hubungannya dengan Kegiatan Belajar Siswa: Studi pada Sekolah Menengah Atas Padang. Tesis. Program Pascasarjana Universitas Negeri Padang. 